\title{
Chen Yung-Fa, Zhongguo gongchan geming qishi
} nian

Taiwan, Lianjing chuban shiye gongsi, 1st edition: 1998, 2nd edition: 2001, 2 Vols, 1, 146 p.

Thi Minh-Hoang Ngo

\section{CpenEdition} Journals

Édition électronique

URL : http://journals.openedition.org/chinaperspectives/793

DOI : 10.4000/chinaperspectives.793

ISSN : 1996-4617

Éditeur

Centre d'étude français sur la Chine contemporaine

Édition imprimée

Date de publication : 1 février 2004

ISSN : 2070-3449

Référence électronique

Thi Minh-Hoang Ngo, «Chen Yung-Fa, Zhongguo gongchan geming qishi nian », China Perspectives [En ligne], 51 | january-february 2004, mis en ligne le 23 avril 2007, consulté le 24 septembre 2020. URL: http://journals.openedition.org/chinaperspectives/793 ; DOI : https://doi.org/10.4000/ chinaperspectives.793

Ce document a été généré automatiquement le 24 septembre 2020

(c) All rights reserved 


\section{Chen Yung-Fa, Zhongguo gongchan geming qishi nian}

Taiwan, Lianjing chuban shiye gongsi, 1st edition: 1998, 2nd edition:

2001, 2 Vols, 1, 146 p.

Thi Minh-Hoang Ngo

\section{NOTE DE L'ÉDITEUR}

Translated from the French original by Jonathan Hall

1 Chen Yung-Fa, the author of an authoritative study of the Chinese communist revolution, Making Revolution ${ }^{1}$, provides us here with an excellent overview, covering seventy years of that revolution, from the early beginnings of the Chinese Communist Party (CCP) in the 1920s until the 1990s. In Making Revolution, he showed that during the Sino-Japanese war the revolution was far from being the outcome of spontaneous mass movements. In fact, it was brought about by localised political activity aimed at organising the CCP in the countryside in central and eastern China. During the war, the question of building the single party state was of central importance. Not only does the author reaffirm this fundamental point, but he also demonstrates the importance of the communist leaders' ideological outlook and their perceptions of the revolutionary process. Clearly, this gives us the classical outlines of a general history of Chinese communism, in which the currents of ideas and the events affecting the national situation are traced out, both in their international context and through the directions pursued by the different leading figures, showing their reciprocal influences. Such interactions involved not only the charismatic leaders of the CCP: Chen Duxiu, Mao Zedong and Deng Xiaoping, but also the Soviet leaders and advisers, and other figures who were behind the peasant uprisings. The political and social issues are clearly laid out and provide the basis for some remarkable analyses and overviews of the main events of the revolution. The author's perspectives on the history of the Chinese revolution are extremely well informed. He emphasises that it was carried forward by 
the elite members of the Party and society, and his careful use of terminology allows us to grasp the distinctions between the different social layers and personality types involved.

The work is divided chronologically into three sections: "Taking power", from the early 1920s to 1949; "Uninterrupted revolution", from the 1950s until the end of the Cultural Revolution; and finally, "Good-bye to revolution". This division works well, throwing light on how the leading figures shaped the revolutionary process through their ideology, their acts, and their mutual confrontations. Society is described in analytical detail and within a broader overview, with particular attention being paid to the problems arising from state control by a single party, and to the limits of the autonomy permitted to the various social players, in particular the different categories of intellectual. The author is careful to distinguish the social reality from constructs belonging to the purely ideological realm, such as the "rich peasant" category. This was devised by the CCP for political ends, but it generally informs the analysis to be found in Party documents.

3 To explain the defeat of the Kuomintang (KMT), the author identifies three basic problems associated with the building of the power of the CCP: nationalism, the organisation of power at the grassroots, and ideological reform and control. In all three areas, the CCP succeeded where the KMT failed. The support of the masses (particularly the poor peasantry), an excellent military strategy, and a political strategy aimed at gaining the support of leading sections of the middle and upper classes, who were disillusioned with the KMT, all combined to give military and political victory to the CCP. In order to explain the subsequent history, the author puts the question in the following way: what were the reasons for the successful economic modernisation of Taiwan, while the CCP failed to follow the "ideal" path of modernisation set by Europe and the United States? This approach, however, is problematical insofar as it adopts a predetermined "Western" perspective.

4 The author shows us the unprecedented control exercised over rural and urban society by the single party state, operating through local cells and work units isolated from each other. The lack of economic and cultural freedom increased after the 1957 campaign against intellectuals and counter-revolutionaries and the Great Leap Forward. The latter, by completely suppressing the commercial economy, led downwards towards a "natural" subsistence economy. But he also shows us that, within the context of developing Chinese nationalism at the time, the problem confronting the intellectuals was less a question of modernising China along "Western" lines than of defining a Chinese road to modernity.

5 Chen emphasises that at first, before it became a matter for professional revolutionaries, the communist revolution was the concern of a small group of idealist intellectuals, influenced by the anarchist and Marxist-Leninist ideas which they had discovered in Japan. And the participation of all intellectuals was vigorously encouraged by the Party up until the campaign against counter-revolutionaries in 1957. The development of the Party's ideology is situated in the context of its relations with Sun Yat-Sen, the KMT, and the Comintern. The author emphasises the lasting influence of anarchism as well as the CCP's dependence on the Comintern, particularly in terms of finance and the role played by Russian advisers in formulating revolutionary strategy. 
6 The reader is reminded that the peasant movements of 1926-27 were launched by intellectuals from the great rural families, like Peng Pai and Shen Dingyi. The author also gives us a remarkable analytical description of the workers' movement of the 1920s. Relying on the authoritative works of Jean Chesneaux and Elizabeth Perry, he shows that, despite competition from other workers' movements, the CCP established a foothold in working class areas and strengthened its position within the United Front, by operating within the legal and semi-legal limits permitted by the KMT. This strategy gave reassurance to the workers. After the workers' strikes of 1925, the CCP members who had entered the KMT attempted to take control by relying on a strengthening of the party through rallying the workers. But this was not a premeditated plan. The strategy of the KMT was then to push the CCP towards illegal forms of struggle, and this led to the repression of 1927 and the end of the first United Front.

Chen Yung-Fa also dismantles certain myths, like that of Chen Yonggui, glorified by Mao as a national hero during the Cultural Revolution. We learn that this secretary of the production team at Dazhai achieved the total collectivisation of land and the means of production by recourse to force and physical violence, and not by following the Party's principles and recompensing peasants in accordance with their work conduct and their ideological conformity.

8 To sum up, this work gives an authoritative account of the communist movement in China, and is lively, remarkably well documented, and pleasurable to read. However it lacks a critical introductory analysis of its main sources, like the biography of Mao by Xing Zilin ${ }^{2}$.

\section{NOTES}

1. Chen Yung-Fa, Making Revolution: The Chinese Communist Movement in Central and Eastern China, 1937-1945, Berkeley, University of California Press, 1986.

2. Xing Zilin, Mao Zedong quan zhuan, Hong Kong, Liwen chubanshe, 1997. 